\title{
UNIVERSITY OF TEXAS RADIOCARBON DATES IV
}

\author{
F. J. PEARSON, JR., E. MOTT DAVIS, and M. A. TAMERS* \\ Radiocarbon Dating Laboratory, Balcones Research Cienter, \\ The University of Texas, Austin
}

This list reports routine measurements made at this laboratory since the preparation of the last list (Texas III). It also includes measurements made on bone samples earlier as part of a study of the suitability of bone for $\mathrm{C}^{1+}$ dating (Tamers and Pearson, 1965). In the absence of the laboratory director, M. A. Tamers, who has been on leave at the Caracas (IVIC) laboratory since October, 1963, laboratory operation and the selection and description of geologic samples have been handled by Pearson, and laboratory administration and archaeologic samples by Davis.

Ages are calculated using a $\mathrm{C}^{14}$ half-life of 5568 yr with 1950 the reference year. The modern standard used for all samples is $95 \%$ of NBS oxalic acid. The deviations reported are based on the counting statistics of the sample, background, and modern, and are $\pm 1_{\sigma}$ except that when the sample count approaches either the modern or the background, $2 \sigma$ limits are reported. Users of these dates should bear in mind that the $\mathrm{C}^{1+}$ content of the atmosphere has varied by several percent during the last several milliennia. This variation may be assumed to contribute an additional uncertainty equivalent to a standard deviation of $100 \mathrm{yr}$. Taking this uncertainty into account, an estimate of $l_{\sigma}$ errors associated with dates in this and the earlier Texas lists may be found from the expression

$$
\sqrt{(100)^{2}+(\text { published error })^{2}}
$$

The laboratory continues to use liquid scintillation counting of benzene. The method of benzene synthesis was changed during the summer of 1965 from the method using $\mathrm{SrC}_{2}$ and $\mathrm{B}_{2} \mathrm{H}_{6}$-activated catalyst (Texas II, III) to one using $\mathrm{Li}_{2} \mathrm{C}_{2}$ and vanadium-activated catalyst (Noakes et al., 1966). The sample-preparation time remains about the same with the new method as with the old, but the chemical yields, which formerly averaged about $50 \%$, now average about $80 \%$ and are considerably more constant. As before, no radon has been observed, nor is the synthesized benzene quenched. Samples numbered through Tx-260 were prepared using the $\mathrm{SrC}_{2}$ method; beginning with $\mathrm{Tx}-262$ the $\mathrm{Li}, \mathrm{C}_{\text {, }}$ method was used. Samples Tx-245, -249, -259, -261, and -269 were split and run by both methods.

The samples are counted in a liquid scintillation spectrometer equipped with two channels and a print-out device. The details of the counting procedure are similar to those described by Tamers (1966). The counter efficiency is determined daily using a "hot" reference sample

* On leave until September 1966 at: Instituto Venezolano de Investigaciones Cientificas, Caracas, Venezuela. 
calibrated against the NBS standard, and the absence of quenching is verified for each sample using the channels-ratio method (Noakes et al., 1966; Tamers, 1966).

The benzene syntheses using the $\mathrm{SrC}_{2}$ method were carried out by B. J. Bowen. Those using the $\mathrm{Li}_{2} \mathrm{C}_{2}$ method were performed by $\mathrm{R}$. B. Wiggins, who also assisted in setting up the $\mathrm{Li}_{2} \mathrm{C}_{2}$ apparatus and stabilizing the technique. We continue to be grateful to Miss Jo Anne Nowick for her able assistance in laboratory administration and preliminary sample processing.

\section{KNOWN-AGE BONE SAMPLES}

The following are bone samples dated to determine the suitability of this material for $\mathrm{C}^{14}$ dating. All samples were found in close association with charcoal which has also been dated and provides control ages. Names of collectors and submitters, and details of the associations of these samples, are given in the reports of the charcoal equivalents referred to in the table of results. The complete study, including results of other bone samples run at the Caracas (IVIC) laboratory (Caracas II) has been presented elsewhere (Tamers and Pearson, 1965) but a summary of the conclusions is appropriate here.

All samples were thoroughly scrubbed, rinsed with dilute acid, and dried. The clean dry bone was dissolved in an excess of acid and the residue evaporated to dryness. The dry residue was burned in the usual way and is reported as fraction $\mathrm{A}$. Some of the $\mathrm{CO}_{2}$ evolved during the acid treatment was also dated and is reported as fraction B. Portions of some samples were not dissolved in acid but were burned directly and are reported as fraction $\mathrm{C}$.

From the table, it is clear that fraction $\mathbf{B}$, the carbonate portion of the bones, in all cases contained more $\mathrm{C}^{14}$ than the associated charcoal. This is probably due to exchange between the carbonate and $\mathrm{CO}_{2}$ of the atmosphere. (See also comment on Tx-253, below). Bone carbonate is probably also present in fraction $\mathrm{C}$, especially if burning was carried out at a high temperature. Thus fractions $\mathrm{B}$ and $\mathrm{C}$ are not likely to yield reliable dates.

In seven of the fourteen samples studied, the $\mathrm{C}^{14}$ content of the organic (A) fraction was statistically indistinguishable from that of the control. This result agrees with the conclusions of other workers (Berger et al., 1964; Krueger, 1966) that organic fraction dates are reliable. However, the $\mathrm{C}^{14}$ ages of the seven remaining samples were younger than those of the controls by as much as several thousand years. We attribute this behavior, which has also been reported by others (c.g. LCLA-705, UCLA IV), to the fact that these samples were all buried bone and were sufficiently impregnated with soil and debris so that even with the most scrupulous cleaning it probably was not possible to remove completely the younger material. Therefore, unless we are certain the bone has been protected from contact with possible contaminants throughout its history (e.g. Tx-51, Texas II), we now treat bone measurements as giving 
lower limiting ages only and report them as "greater than" the calculated age minus $2 \sigma$ (see table and Tx-164, -250, -253).

TABLE 1

Bone Results

\begin{tabular}{|c|c|c|c|c|}
\hline $\begin{array}{c}\text { Bone } \\
\text { Sample } \\
\text { Number }\end{array}$ & $\begin{array}{c}\delta \mathrm{C}^{14} \\
\text { bone } \\
(\% \circ)\end{array}$ & Bone Age & $\begin{array}{l}\text { Assoc. } \\
\text { Charcoal } \\
\text { Sample }\end{array}$ & $\begin{array}{c}\text { Assoc. } \\
\text { Charcoal } \\
\text { Age \& } \delta C^{14}\end{array}$ \\
\hline
\end{tabular}

Fort St. Louis, Texas

$\begin{array}{lr}\text { Tx-162-1 } & -1 \pm 14 \\ \text { Tx-162-B } & +35 \pm 13 \\ \text { Tx-162-C } & -16 \pm 11 \\ & \\ \text { Tx-163-A } & -59 \pm 11 \\ \text { Tx-163-B } & +34 \pm 15 \\ \text { Tx-163-C. } & -65 \pm 21\end{array}$

$\begin{array}{ll} & \\ \text { Tx-47-A } & -295 \pm 13 \\ \text { Tx-229-A } & -283 \pm 57 \\ \text { Tx-229-B } & -176 \pm 11 \\ \text { Tx-229-C } & -233 \pm 110\end{array}$

modern

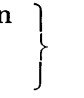

$\left\{\begin{array}{l}\mathrm{Tx}-48 \\ \text { (Texas II) }\end{array}\right.$

$195 \pm 105 \mathrm{yr}$

San Lorenzo, Texas

$>290 \mathrm{yr}$

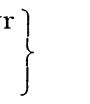

$\left\{\begin{array}{l}\text { Tx }-49 \\ (\text { Texas II })\end{array}\right.$

Bonfire Shelter, Texas

Bone Bed 3

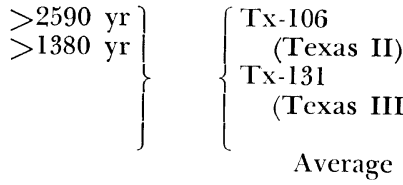

Bone Bed 2

$\begin{array}{lll}\text { Tx-230-A } & -606 \pm 8 & >7,150 \mathrm{yr} \\ \text { Tx-230-B } & -586 \pm 8 & >8,720 \mathrm{yr} \\ \text { Tx-231-A } & -679 \pm 8 & \\ \text { Tx-231-B } & -595 \pm 8 & \\ \text { Tx-231-C. } & -682 \pm 8 & \\ \text { Tx-118-A } & -648 \pm 8 & >8,020 \mathrm{yr} \\ \text { Tx-232-A } & -678 \pm 8 & >8,660 \mathrm{yr} \\ \text { Tx-232-B } & -594 \pm 19 & \end{array}$

II. GEOLOGIC AND PALEONTOLOGIC SAMPLES

\section{A. Texas Vertebrate Faunas}

The following are bone samples of unknown age from various Texas vertebrate faunas. All were treated as described above, and the ages reported are the lower limiting ages $(2 \sigma)$ based on the organic (A) fraction. The measured $\mathrm{C}^{14}$ contents of the fractions are given in the descriptions. All samples subm. by E. L. Lundelius, Jr., Dept. of Geology, Univ. of Texas, Austin. Comments by E. L. L.

Tx-164. Tedford Quarry

Fragments of turtle carapace from Tedford Quarry near Ingleside,

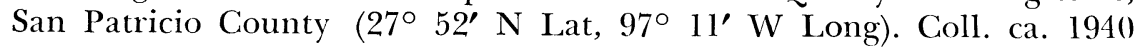


from 6 to $15 \mathrm{ft}$ below surface in fresh water pond deposit of Ingleside barrier chain (Price, 1958). $\delta \mathrm{C}^{14}-\mathrm{A}=-860 \pm 28 \%\left(\delta \mathrm{C}_{14}-\mathrm{B}=-666 \pm 9 \%\right.$, $\delta \mathrm{C}^{14} \mathrm{C}=-722 \pm 8 \%$. Comment: Ingleside fauna is late Pleistocene and is very probably older than $12,000 \mathrm{yr}$ as clate suggests.

\section{Tx-250. Cave Without a Name}

Bone from Cave Without a Name, ca. $9 \mathrm{mi} \mathrm{NE}$ of Boerne, Kendall County $\left(29^{\circ} 53^{\prime} \mathrm{N}\right.$ Lat, $98^{\circ} 37^{\prime} \mathrm{W}$ Long). From undisturbed clay deposit at bottom of entrance shaft. Coll. 1960 by E. L. Lundelius, Jr. $\delta \mathrm{C}^{1+4}-\mathrm{A}=$ $-745 \pm 6 \%, \delta \mathrm{C}^{14}-\mathrm{B}=-700 \pm 8 \%$. Comment: sample associated with Wisconsin vertebrate fauna with many extinct and extant species not now found in Kendall County. Date agrees with previous estimate of 10,000-20,000 yr B.P.

\section{Tx-253. Felton Cave}

Bone from accumulation of vertebrate remains in Felton Cave, ca. $10 \mathrm{mi} \mathrm{S}$ of Sonora, Sutton County $\left(33^{\circ} 28^{\prime} \mathrm{N}\right.$ Lat, $100^{\circ} 33^{\prime} \mathrm{W}$ Long). Sample from 12 to $21 \mathrm{in}$. below surface of cave fill on $\mathrm{N}$ side of entrance room. Coll. 1965 by R. M. Frank. $\delta \mathrm{C}^{1 \cdot 4}-\mathrm{A}=-620 \pm 6 / \%, \delta_{1 \cdot 1}-\mathrm{B}=$ $-657 \pm 6 \%$. Comment (F.J.P.): this is only bone sample we have run in which $\mathrm{B}$-fraction contains less $\mathrm{C}^{14}$ than A-fraction. It is possible that $\mathrm{C}^{14}$ content of $\mathrm{CO}_{2}$ in cave atmospheres may be lowered by exchange with or dilution by "dead" limestone. This anomaly might then be clue to exchange between the bone carbonate and such $\mathrm{CO}_{2}$. (E.L.L.): this is an early Recent fauna with two species whose present ranges are restricted to the wetter area of $\mathrm{E}$ Texas. Date suggests that desiccation of this area which drove these species E began earlier than expected.

\section{Bahia Salada Core III}

\section{B. Western Gulf Coast}

Shell fragments from core in recent lagoonal-marine sediments under Bahia Salada, Tamaulipas, Mexico $\left(24^{\circ} 30^{\prime} \mathrm{N}\right.$ Lat, $97^{\circ} 45^{\prime} \mathrm{W}$ Long), dated to determine rate of sedimentation. Core from $200 \mathrm{~m}$ inside (W of) mouth of bay, adjoining Mexican Laguna Madre. Coll. Nov. 1964 by E. W. Behrens and R. F. Leo; subm. by P. L. Parker, Inst. of Marine Science, Univ. of Texas, Port Aransas, Texas.

Tx-247. Bahia Salada Core III-J; CD-4

$900 \pm 75$

$75 \mathrm{~cm}$ below sediment-water interface. $\delta \mathrm{C}^{14}=-107 \pm 8 \%$.

$1750=80$

Tx-248. Bahia Salada Core III-K; CD-5

A.D. 200

$150 \mathrm{~cm}$ below sediment-water interface. $\delta \mathrm{C}^{14}=-195 \pm 8 \% \mathrm{c} . \mathrm{Com}-$ ment (E.W.B.): these dates indicate an average rate of sedimentation of 
$0.8 \mathrm{~mm} / \mathrm{yr}$. Other samples from this core were analyzed for concentrations of fatty acids. These concentrations showed no correlation with depth. However, the ratios of saturated to unsaturated acids appear to increase with depth.

\section{Tx-249. Laguna Madre CD-6}

$1940 \pm 60$

Fossil beach shells, including the genera Aequipecten, Busycon, Dinocardium, Fasciolaria, Polinices, and Macrocallista, from ca. $8 \mathrm{ft}$ above sealevel in a bluff on NE shore of Bahia Salada near point where this bay enters Laguna Madre, near Carvajal, Tamaulipas, Mexico $\left(24^{\circ}\right.$ $30^{\prime} \mathrm{N}$ Lat, $97^{\circ} 45^{\prime} \mathrm{W}$ Long). Another sample from same location was dated at $2340 \pm 100$ (Tx-154, Texas III). Coll. Nov. 1964 and subm. by E. W. Behrens, Inst. of Marine Science, Univ. of Texas, Port Aransas, Texas.

A portion of this sample was first dated using the $\mathrm{SrC}_{2}$ method giving $\delta \mathrm{C}^{14}=-213 \pm 7 \%$, about 400 yr younger than the presumably equivalent Tx-154. To determine if the difference could be due to exchange with the atmosphere at the shells' surface, the $\mathrm{CO}_{2}$ evolved from another portion of the sample was split into three parts corresponding roughly to the outer, middle, and inner thirds of the shells. The fractions were separately prepared by the $\mathrm{Li}_{2} \mathrm{C}_{2}$ method and the $\delta \mathrm{C}^{14}$ 's were: Outer 1/3: $-212 \pm 9 \%$; Middle 1/3: $-221 \pm 8 \%$; Inner 1/3: $-208 \pm 9 \%$. No exchange could be demonstrated and the four mcasurements were averaged to give the date above. The discrepancy between this date and Tx154 remains unexplained, although it is less than $3 \sigma$ and therefore may not be real. Comment (E.W.B.) : this, with an earlier sample-TX-154-is the first reported evidence from the Gulf of Mexico of a Recent stand of sealevel higher than the present position. Deposit may reflect local uplift, but date correlates with dates obtained from similarly elevated deposits from Brazil and Australia (vanAndel and Laborel, 1964; Fairbridge, 1961).

\section{Tx-264. Aransas Pass Shells}

Fresh-water shells (Physa and Planorbis) from spoil island $13 / 4 \mathrm{mi}$ $\mathrm{NE}$ of Intracoastal Waterway Bridge near Aransas Pass $\left(27^{\circ} 53^{\prime} \mathrm{N}\right.$ Lat, $97^{\circ} 06^{\prime} \mathrm{W}$ Long). From fresh-water pond deposits now ca. $15 \mathrm{ft}$ below sealevel on seaward side of Ingleside barrier (Price, 1958). Coll. 1961 by H. D. Hoese; subm. by E. L. Lundelius, Jr., Dept. of Geology, Univ. of Texas, Austin. $\delta \mathrm{C}^{14}=0 \pm 5 \%$. Comment (E.L.L.): these pond deposits were formed when sealevel was below level at which Tedford Quarry deposits were formed, and it was hoped this date, with $\mathrm{Tx}-164$ (this list), would give the relative ages of the deposits. The hope was not fulfilled, but the present date does add to our knowledge of the history of the western Gulf Coast. 


\section{Eastern Texas}

\section{Deweyville Terrace series}

Wood samples from Deweyville terraces, the first stream terraces above the recent terrace along most rivers of eastern Texas (Bernard and LeBlanc, 1965). Coll. 1965 and subm. by Saul Aronow, Dept. of Geology, Lamar State College of Technology, Beaumont, Texas, via P. T. Flawn, Bur. of Economic Geology, Univ. of Texas, Austin. Wood identification by Texas Forest Products Lab. Lufkin, and Forest Products Lab., Madison, Wisconsin.

\section{Tx-266. Deweyville 1}

$25,700 \pm 800$

Red oak wood from Deweyville Specialty Sand Co. pit ca $1 / 2 \mathrm{mi} \mathrm{N}$ of Deweyville, Newton County ( $30^{\circ} 19^{\prime} \mathrm{N}$ Lat, $93^{\circ} 45^{\prime} \mathrm{W}$ Long). Removed from pit by suction hose from reported depth of 15 to $20 \mathrm{ft}$ from surface. $\delta \mathrm{C}^{14}=-959 \pm 4 \%$.

\section{Tx-267. Deweyville 2}

$$
19,900 \pm 500
$$

Hickory wood, probably pecan, from Urbana Sand and Gravel Co. pit, ca. $0.8 \mathrm{mi} \mathrm{SW}$ of Urbana, San Jacinto County $\left(30^{\circ} 39^{\prime} \mathrm{N} \mathrm{Lat}, 94^{\circ}\right.$ $57^{\prime} \mathrm{W}$ Long). Removed from pit by dragline from reported depth of 20 to $30 \mathrm{ft}$ below surface. $\delta \mathrm{C}^{14}=-916 \pm 5 \%$.

\section{Tx-268. Deweyville 3}

$13,250 \pm 250$

Sycamore wood from Cleveland Sand and Gravel Co. pit, ca. $1.3 \mathrm{mi}$ NW of Cleveland, Liberty County ( $30^{\circ} 21^{\prime} \mathrm{N}$ Lat, $95^{\circ} 07^{\prime} \mathrm{W}$ Long). Removed from pit by dragline from reported depth of 15 to $30 \mathrm{ft}$ below surface. $\delta \mathrm{C}^{14}=-808 \pm 6 \%$.

General Comment (S.A.): Deweyville Terraces have been considered early Recent, but these dates are all older than Two Creeks, suggesting the terraces are late Pleistocene.

\section{Western Texas}

Samples from pluvial lakes in NW Texas dated to determine chronology of the sediments in these lakes. The problem is discussed in detail by Reeves (1966).

\section{Mound Depression series}

Organic mud samples from core in playa of Mound Lake, Lynn and Terry Counties, Texas ( $33^{\circ} 13^{\prime} \mathrm{N}$ Lat, $102^{\circ} 5^{\prime} \mathrm{W}$ Long). Core taken off the drilling pad on road leading to large central island. Coll. 1965 and subm. by C. C. Reeves, Jr., Dept. Geosciences, Texas Tech. College, Lubbock, Texas. 
Tx-270. ML 2

$31,800+3700$

Depth $2 \mathrm{ft} ; \delta \mathrm{C}^{14}=-981 \pm 7 \%$.

29,850 B.C.

Tx-271. ML 7

$33,000 \pm 2500$

Depth $7 \mathrm{ft} ; \delta \mathrm{C}^{14}=-983 \pm 5 \%$.

31,050 B.C.

Tx-272. ML 8

Depth $8 \mathrm{ft} ; \delta \mathrm{C}^{14}=-990 \pm 4 \%$.

$37,000+2100$

35,050 в.c.

$>34,300$

Tx-273. ML 15 $1 / 2$

Depth $151 / 2 \mathrm{ft} ; \delta \mathrm{C}_{14}=-996 \pm 5 \%$.

Comment (C.G.R.): in this core, contact between kaolinitic and overlying montmorillonitic clays is at ca. $20 \mathrm{ft}$. This suggests lake fill is pre-Tahoka, not Tahoka or Recent.

\section{T-Bar Depression series}

Dolomite samples from $\mathrm{N}$ end of $\mathrm{S}$ lake in T-Bar Depression, Lynn County, Texas ( $33^{\circ} 12^{\prime} \mathrm{N}$ Lat, $101^{\circ} 55^{\prime} \mathrm{W}$ Long). Coll. 1964 and subm. by C. C. Reeves, Jr.

Tx-262. TBS 2

$20,300 \pm 300$

From upper dolomite. $\delta \mathrm{C}^{14}=-920 \pm 6 \%$. 18,350 B.c.

Tx-263. TBS 1

From lower dolomitc. Sample split; $\delta \mathrm{C}^{14}=-914 \pm 8 \%$, and $-916 \pm$ $5 \%$; date from average.

General Comment (C.C.R.): samples are from mid-part of Tahoka clay and correlate with dolomite found in mid-part of the Tahoka in other basins. Dates represent Vigo Park period of desiccation.

\section{Tx-245. Newberry Crater, Oregon \\ $1270 \pm 60$}

Charcoal from beneath topmost pumice layer within caldera of Newberry volcano $\left(43^{\circ} 43^{\prime} \mathrm{N}\right.$ Lat, $121^{\circ} 15^{\prime} \mathrm{W}$ Long), Oregon. From exposure in roadcut between East and Paulina Lakes near point of collection of C-657 (2054 \pm 230 , Libby, 1955), which should be equivalent. Coll. and subm. 1964 by U. S. Clanton, NASA Manned Spacecraft Center, Houston. Sample run twice by $\mathrm{SrC}_{2}$ method giving $\delta \mathrm{C}^{14}=-152 \pm 8 \%$ o and $-153 \pm 10 \%$ and by $\mathrm{Li}_{2} \mathrm{C}_{2}$ method giving $\delta \mathrm{C}^{14}=-132 \pm 9 \%$. Date is average of three runs. Comment (U.S.C.): pumice bed is capped by an obsidian flow which appears to be last volcanic activity within caldera; sample thus establishes maximum age for last event. 


\section{F. Miscellany}

\section{Tx-261. Modern Oak leaves}

$$
\delta \mathbf{C}^{14}=\mathbf{5 5 5} \pm \mathbf{6} \%
$$

Leaves from live oak trees growing on grounds of Balcones Research Center, Austin, Texas (30 23' N Lat, $97^{\circ} 44^{\prime}$ W Long). Coll. Sept. 1963 by G. M. Dotson; subm. by M. A. Tamers, this lab. A large quantity of these leaves was burned and converted to $\mathrm{SrCO}_{3}$ at time of collection. A portion was measured in May 1964 and had $\delta \mathrm{C}^{14}=+534 \pm 14 \%$. Three lots of $\mathrm{CO}_{2}$ from the same $\mathrm{SrCO}_{3}$ were processed in Aug. 1965, to test the $\mathrm{Li}_{2} \mathrm{C}_{2}$ method. The $\delta \mathrm{C}^{14}$ 's were $+576 \pm 11 \%$ o $+557 \pm 11 \%$, and $+553 \pm$ $11 \%$. The value given above is the average of the four measurements.

\section{Tx-269. Appleton, Wisconsin}

$10,750 \pm 210$

8800 B.C.

Sample from $\log$ dated and reported previously ( $\mathrm{Tx}-44,10,700 \pm 210$, Texas II). Rerun using $\mathrm{Li}_{2} \mathrm{C}_{2}$ method. $\delta \mathrm{C}^{14}=-738 \pm 7 \%$. Comment: in excellent agreement with earlier determination.

III. ARCHAEOLOGIC SAMPLES

\section{A. Lower Pecos River Region, Texas}

For a summary of the chronological situation in this region see Texas II, p. 151, and Texas III, p. 301.

\section{Tx-227. Cammack Sotol pit}

$625 \pm 185$

Charcoal from occupation area just NE of main midden, Cammack Sotol pit (41 VV 260), W bank of tributary of Cow Creek, approx. $2 \mathrm{mi}$ SE of Comstock, Val Verde County, Texas $\left(28^{\circ} 38^{\prime} \mathrm{N}\right.$ Lat, $101^{\circ} 10^{\prime} \mathrm{W}$ Long). From Trench III, 1.5 to $2.0 \mathrm{ft}$ below surface, in Units \#10 and 11. Associated with arrow points with contracting and rectangular stems like those in Toyah, Austin, and Livermore foci and in Bravo Valley aspect. These associations suggest date of A.D. 1200-1300. Coll. 1964 by J. W. Greer; subm. by C. D. Tunnell, Texas Archeol. Salvage Project, Univ. of Texas, Austin. $\delta \mathrm{C}^{14}=-75 \pm 21 \%$. Comment (J.W.G.): date agrees well with preliminary estimate.

\section{B. Central Texas}

For a summary of Central Texas archaeological chronology see Texas II, p. 144-145.

\section{Britton site series}

Charcoal samples from Britton site (41 ML 37; Story and Shafer, 1965, p. 76-135), a buried alluvial terrace site on $\mathrm{E}$ side of $\mathrm{N}$ Bosque $\mathrm{R}$, ca. $7 \mathrm{mi} \mathrm{NW}$ of Waco, Texas ( $31^{\circ} 37^{\prime} \mathrm{N}$ Lat, $97^{\circ} 22^{\prime} \mathrm{W}$ Long). Materials in approx. the upper $6 \mathrm{ft}$ of deposit represented an unmixed component of Transitional period of Archaic Edwards Plateau aspect. Cultural assignment of the few materials found more deeply buried in the 
terrace fill is uncertain. Previous dates from site are Tx-200, $2080 \pm 80$, and Tx-201, $2330 \pm 80$ (Texas III), both from hearth $8 \mathrm{ft}$ below surface. The only other Transitional Edwards Plateau aspect date from this region is Tx-28, $1165 \pm 120$ (Texas II) from Smith shelter; like the other Smith shelter dates (Tx-21 through Tx-28, Texas II) it is $300-400 \mathrm{yr}$ more recent than archaeological evidence warrants. Coll. 1964 and subm. by Dee Ann Story, Texas Archeol. Salvage Project, Univ. of Texas, Austin.

\section{Tx-233. Britton 184}

$1865 \pm 95$

From Feature 35, a hearth and associated mussel and snail shells and a fer burned rocks, 4.0 to $4.2 \mathrm{ft}$ below surface. $\delta \mathrm{C}^{14}=-208 \pm 10 \%$.

\section{Tx-234. Britton 209}

$$
1940 \pm 110
$$

From Feature 48, a hearth exposed in $\mathrm{N}$ end and parts of $\mathrm{W}$ wall of Trench $19,8.5$ to $9.0 \mathrm{ft}$ below surface. $\delta \mathrm{C}^{14}=-216 \pm 9 \%$. Comment (D.A.S.): the four Britton site dates now at hand are consistent with cultural and geologic findings, indicating a time around beginning of Christian era for Transitional period of Edwards Plateau aspect, and a relatively rapid accumulation of alluvium at the site.

\section{Caddoan Area, Texas-Louisiana}

The following samples pertain to the chronology of the Caddoan archacological area in adjacent parts of Texas and Louisiana. For a summary of Caddloan chronology see Texas II, p. 154.

\section{Harroun site series, Texas}

Charcoal samples from Harroun site (41 UR 10; Jelks and Tunnell, $1959)$, NE of Ore City, Upshur County, Texas $\left(32^{\circ} 50^{\prime} \mathrm{N}\right.$ Lat, $94^{\circ} 42^{\prime}$ W Long), associated with artifacts of Whelan complex (early Titus focus). Previous dates for this same complex are: Dalton mound, Tx-83, $480=110$ (Texas II); Harroun site, Tx-84, $490 \pm 100$ (Texas II); Sam Roberts, Tx-199, $320 \pm 60$ and Tx-202, $240 \pm 90$ (Texas III). Coll. 1958 by E. B. Jelks and C. D. Tunnell, Texas Archeol. Salvage Project, Univ. of Texas, Austin; subm. by Jelks.

Tx-238. Harroun site No. 2

$$
265 \pm 65
$$

From Mound B, Sq. N105-W90, elev 98.92 ft. $\delta \mathrm{C}^{14}=-33 \pm 8 \%$.

\section{Tx-239. Harroun site No. 3}

$$
\mathbf{3 3 0} \pm \mathbf{1 1 0}
$$

From Mound C, Sq. N114-W105, elev 99.8 ft. SW edge of Houses 1

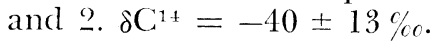

Tx-240. Harroun site No. 1

$555 \pm 70$

From Mound C, Sq. N115-W100, elev 100.2 ft. $\delta \mathrm{C}^{14}=-67 \pm 8 \%$. 


\section{Tx-241. Harroun site No. 4}

From beam above floor of House 4, Mound D. Elev $97.66 \mathrm{ft} . \delta \mathrm{C}^{14}=$ $-42 \pm 9 \%$.

General Comment (C.D.T. and E.M.D.): the 8 dates now at hand for the Whelan complex, taken as a group, indicate a time between A.D. 1400 and 1700. On archaeological evidence Whelan complex is the penultimate prehistoric complex in this area, preceding the prehistoric Titus focus cemeteries. Therefore, the earlier part of the indicated $\mathrm{C}^{1 \pm}$ time range is the most likely dating.

\section{Knight's Bluff series, Texas}

Charcoal samples from Knight's Bluff site (41 CS 14; Jelks, 1961, p. 11-41), ca. $6 \mathrm{mi} \mathrm{NE}$ of Douglassville, Cass County, Texas, on S bank Sulphur R, in Texarkana Reservoir basin $\left(30^{\circ} 15^{\prime} \mathrm{N}\right.$ Lat, $94^{\circ} 15^{\prime} \mathrm{W}$ Long). Samples are believed to be associated with Texarkana focus-like occupation. Coll. 1952 and subm. by E. B. Jelks.

\section{Tx-242. Knight's Bluff 2}

$550 \pm 90$

From grave fill, Burial \#5, adjacent to skull. Association with burial could have been fortuitous, but may date Texarkana focus-like occupation. $\delta \mathrm{C}^{14}=-66 \pm 10 \%$.

\section{Tx-243. Knight's Bluff 5}

$680 \pm 70$

From Sq. E120-N5, 18 in. below surface. Association with Texarkana focus-like occuption not certain, but probable. Date average of two measurements: $\delta \mathrm{C}^{14}=-81 \pm 9 \%$ and $-81 \pm 12 \%$.

General Comment (E.B.J.): dates are in agreement within $l_{\sigma}$ and are within estimated time range of Texarkana focus.

\section{Coral Snake mound series, Louisiana}

Charcoal samples from Coral Snake mound (16 SA 48), $2 \mathrm{mi} \mathrm{E}$ of Pendleton Crossing of Sabine River, $20 \mathrm{mi}$ SW of Many, Sabine Parish, Louisiana ( $31^{\circ} 28^{\prime} \mathrm{N}$ Lat, $93^{\circ} 42^{\prime} \mathrm{W}$ Long). Mound contained cremations, copper artifacts, rocker stamped sherds, and other items, indicating that it is pre-Caddoan and may represent western fringe of Marksville culture. Coll. 1965 and subm. by Burney B. McClurkan, Texas Archeol. Salvage Project, Univ. of Texis, Austin. Comments by E.M.D.

\section{Tx-244. Coral Snake 2}

$210 \pm 90$

From NW quadrant of mound, coordinates N511.00/E 487.45 , elev 100.50. No direct associations. $\delta \mathrm{C}^{14}=-26 \pm 11 \%$. Comment: evidently intrusive. 
Ex-265. Coral Snake 207

$1650 \pm 90$

From base of hemispherical fire pit in central portion of mound; coordinates N505/E496, elev 100.57. No artifacts in direct association. $\delta \mathrm{C}^{14}=-186 \pm 9 \%$. Comment: in harmony with current chronological evidence of later part of Marksville time range in lower Mississippi valley (e.g., Ford, 1963, p. 46-7).

\section{Panhandle aspect series}

\section{Panhandle Area}

Charcoal samples from sites of Panhandle aspect in Canadian R valley and Palo Duro Canyon in Texas Panhandle. Most of these sites are pueblo-like villages of Plains Indians whose artifact inventory is related to complexes to the E and NE. Trade sherds from Pueblo area indicate occupation in A.D. 1300-1450. Coll. and subm. by Jack T. Hughes (except as noted), Panhandle-Plains Hist. Mus., Canyon, Texas; site nos. in parentheses are those in Museum files. In most cases samples were split and part sent to Univ. of Wisconsin Center for Climatic Research for cross-check as part of their study of historic climatology in Southern Plains.

\section{Tx-255. Sanford ruin}

$$
700 \pm 90
$$

From shallow midden on $\mathrm{N}$ side of house, in Sanford ruin (A61), now under $\mathrm{S}$ end of Sanford Dam on Canadian R, Hutchinson County $\left(35^{\circ} 42^{\prime} \times\right.$ Lat, $101^{\circ} 33^{\prime} \mathrm{W}$ Long). This was an isolated house with large round living room and smaller adjoining storage rooms. Coll. 1953. $\delta \mathrm{C}^{14}=-83 \pm 10 \%$.

\section{Tx-256. Spring Canyon ruin}

$550 \pm 90$

From midden NE of large rectangular structure at Spring Canyon ruin (A41; Duffield, 1964, p. 48-71), on N side of Canadian R NW of Sanford, Hutchinson County (35 $43^{\prime} \mathrm{N}$ Lat, $101^{\circ} 33^{\prime} \mathrm{W}$ Long). Coll. 1961. $\delta \mathrm{C}^{14}=-66 \pm 11 \%$.

\section{Tx-257. Currie ruin}

\section{A.D. 1120}

$\mathbf{8 3 0} \pm \mathbf{1 0 0}$

From house fill in Currie ruin (A254), S side of Lake Stockton in Palo Duro Canyon, Randall County ( $35^{\circ} 03^{\prime} \mathrm{N}$ Lat, $101^{\circ} 46^{\prime} \mathrm{W}$ Long). This is an isolated house with a single rectangular room. Coll. 1956. (Same field sample as WIS-100, $670 \pm 75$, Wisconsin II.) $\delta \mathrm{C}^{14}=-101 \pm$ $11 \%$.

\section{Tx-258. Coetas ruin}

From room floor, Coetas ruin (A611) S side Coetas Creek 2 mi E of Canadian R, Potter County ( $35^{\circ} 30^{\prime} \mathrm{N}$ Lat, $101^{\circ} 44^{\prime} \mathrm{W}$ Long). Site con- 
sists of several adjoining rectangular houses (Studer, 1934). Coll. 1965. (Same field sample as WIS-95, $800 \pm 75$, Wisconsin II.) $\delta \mathrm{C}^{14}=-52 \pm$ $10 \%$.

\section{Tx-259. Alibates ruin}

\section{A.D. 1470}

$480 \pm 80$

From Room 24, Alibates ruin (A45), E side Alibates Creek 11/2 mi S of Canadian R, Potter County ( $35^{\circ} 34^{\prime} \mathrm{N}$ Lat, $101^{\circ} 40^{\prime} \mathrm{W}$ Long). This is large village with a variety of structures. Coll. 1939 by Ele M. Baker. (Same field sample as WIS-101, $600 \pm 70$, Wisconsin II.) Date average of two measurements: $\delta \mathrm{C}^{14}=-55 \pm 13 \%, \mathrm{SrC}_{2}$ method and $\delta \mathrm{C}^{14}=-6 \mathrm{I} \pm 12 \%, \mathrm{Li}_{2} \mathrm{C}_{2}$ method.

$465 \pm 85$

\section{Tx-260. Palisades shelter}

A.D. 1485

From Sq. 5, 30 to $36 \mathrm{in}$. below surface, in camp debris on talus slope below Palisades shelter (A530), N side Palo Duro Canyon in Palisades Club, Randall County (35 04' N Lat, $101^{\circ} 48^{\prime} \mathrm{W}$ Long). Coll. 1964. (Same field sample as WIS-108, $630 \pm 75$ and $600 \pm 75$, Wisconsin II.) $\delta \mathrm{C}^{14}=-56 \pm 10 \%$.

Comment on Panhandle aspect series (J.T.H.): the radiocarbon dates span the time range indicated by Puebloan sherds in these sites. Archaeological evidence suggests tentatively that larger ruins with more abundant Pueblo traits (e.g., Coetas, Alibates) are later than others, and these $\mathrm{C}^{14}$ determinations lend some support to this suggestion.

\section{E. Northeastern Mexico}

\section{Cueva de la Zona de Derrumbes series, Nuevo Leon}

Charcoal samples from Cueva de la Zona de Derrumbes (site NL-92, listed in Texas III as Cueva de la Zona), ca. $31 \mathrm{~km} \mathrm{~W}$ of Linares, Nuevo Leon, NW Mexico, on the Ejiclo Santa Rosa (24 $45^{\prime} \mathrm{N}$ Lat, $99^{\circ} 49^{\prime} \mathrm{W}$ Long). Samples are from a deposit below a gravel layer $5 \mathrm{ft}$ thick, which in turn underlay a cultural deposit from which came dates previously published (Tx-144 through Tx-150, Tx-204 through Tx-209, Texas III). The earliest date, from just above the gravel, was $4840 \pm 220$ (Tx-150). The present samples, all from Sq. N0/W25 and S5/W25, are from a deposit $2 \mathrm{ft}$ thick under the gravel, containing 3 charcoal zones, Occupation Layers 1, 2, and 3 (from top to bottom). Projectile points from this deposit are of small triangular and lanceolate forms similar to those found immediately above the gravels. Coll. 1964 and subm. by J. F. Epstein, Dept. of Anthropology, Univ. of Texas, Austin. Samples are listed in order of increasing depth.

\section{Tx-254. Zona de Derrumbes C20-GR-TS 2930 в.c.}

From contact of gravel with underlying deposit. $\delta \mathrm{C}^{14}=-456 \pm 7 \%$. 


\title{
Tx-236. Zona de Derrumbes C-21-TS-L1
}

$4700 \pm 120$

From Occupation Layer $1 . \delta \mathrm{C}^{14}=-443 \pm 8 \%$.

2750 B.C.

\section{Tx-237. Zona de Derrumbes C22-TS-L2}

$4755 \pm 110$

From lower part of Occupation Layer 2 and fill immediately below. $\delta \mathrm{C}^{14}=-448 \pm 8 \%$.

\section{Tx-235. Zona de Derrumbes C23-TS-L3}

$4950 \pm 160$

From Occupation Layer $3 . \delta \mathrm{C}^{14}=-459 \pm 11 \%$

General Comment (J.F.E.): the present series is consistent with the series reported in Texas III, and confirms archaeological evidence that no significant time interval is represented by the gravel deposit.

Date lists:

\section{REFERENCES}

\author{
Caracas II Tamers, 1966 \\ Texas II Tamers et al., 1964 \\ Texas III Pearson et al., 1965 \\ UCLA IV Berger el al., 1965 \\ Wisconsin II Bender, Bryson, and Baerreis, 1966
}

Bender, M. M., Bryson, R. A., and Baerreis, D. A., 1966, University of Wisconsin radiocarbon dates II: Radiocarbon, v. 8, p. 522-533.

Berger, Rainer, Fergusson, G. J., and Libby, W. F., 1965, UCI.A radiocarbon dates IV: Radiocarbon, v. 7, p. 336-371.

Berger, Rainer, Horney, A. G., and Libby, W. F., 1964, Radiocarbon dating of bone and shell from their organic components: Science, v. 144, p. 999-1001.

Bernard, Hugh A., and LeBlanc, Rufus J., 1965, Resume of the Quaternary geology of the northwestern Gulf of Mexico province, in Wright, H. E. Jr., and Fres, David G., eds., The Quaternary of the United States: Princeton Univ. Press. p. 137-185.

Duffield, Lathel F., 1964, Three Panhandle Aspect sites at Sanford Reservoir, Hutchinson County, Texas: Texas Archcol. Soc. Bull., v. 35, p. 19-81.

Fairbridge, R. W., 1961, Eustatic changes in sea level: in Physics and Chemistry of the Earth, v. 4, p. 99-185.

Ford, James A., 1963, Hopewell Culture burial mounds near Helena, Arkansas: Amer. Mus. Nat. Hist. Anthropol. Papers, v. 50, pt. 1.

Jelks, Edward B., 1961, Excavations at Texarkana Reservoir, Sulphur River, Texas: Bur. Amer. Ethnology Bull. 179, p. 1-78.

Jelks, Edward B., and Tunnell, Curtis D., 1959, The Harroun Site: Dept. of Anthropol., Univ. of Texas, Archaeol. Ser., no. 2.

Krueger, Harold W., 1966, The preservation and dating of collagen in ancient bones: in Proceedings of the Internat. Carbon-14 and Tritium Dating Conf., Pullman, Washington, 1965, in press.

Libby, W. F., 1955, Radiocarbon dating: 2nd ed., Chicago, Univ. of Chicago Press, $175 \mathrm{p}$.

Noakes, J. E., Kim, S. M., and Stipp, J. J., 1966, Chemical and counting advances in liquid scintillation age dating: in Proceedings of the Internat. Carbon-14 and Tritium Dating Conf., Pullman, Washington, 1965, in press.

Pearson, F. J., Jr., Davis, E. Mott, Tamers, M. A., and Johnstone, Robert W., 1965, University of Texas radiocarbon dates III: Radiocarbon, v. 7, p. 296-314.

Price, W. Armstrong, 1958, Sedimentology and quaternary geomorphology of south Texas: Gulf Coast Assoc. Geol. Soc. Trans., v. 8, p. 41-75. 
Reeves, C. C., Jr., 1966, Pluvial lake basins of west Texas: Jour. Geology, in press.

Story, Dee Ann, and Shafer, Harry J., 1965, 1964 excavations at Waco Reservoir, McLennan County, Texas: the Britton and Baylor sites: Texas Archeol. Salvage Project, Misc. Papers No. 6.

Studer, Floyd V., 1934, Texas Panhandle Culture Ruin No. 55: Texas Archeol. and Paleontol. Soc. Bull. v. 6, p. 80-96.

Tamers, M. A., 1966, Routine carbon-14 dating using liquid scintillation techniques: in Proceedings of the Internat. Carbon-14 and Tritium Dating Conf., Pullman, Washington, 1965, in press.

1966, Instituto Venezolano de Investigaciones Cientificas natural radiocarbon measurements II: Radiocarbon, v. 8, p. 204-212.

Tamers, M. A., and Pearson, F. J., Jr., 1965, Validity of radiocarbon dates on bone: Nature, v. 208, p. 1053-1055.

Tamers, M. A., Pearson, F. J., Jr., and Davis, E. Mott, 1964, University of Texas radiocarbon dates II: Radiocarbon, v. 6, p. 138-159.

vanAndel, T. H., and Laborel, J., 1964, Recent high relative sea level stand near Recife, Brazil: Science, v. 145 , p. $580-581$. 